\title{
Section on Historical Pharmacy, American Pharmaceutical Association
}

\author{
HISTORY OF PHARMACY IN NEW JERSEY IN THE EARLY SIXTIES \\ BY AN APPREN'TICE OF 'THOSE DAYS.*
}

BY L. E. SAYRE.

To learn what were the conditions and transactions in former times is regarded as worthy history. Not to know these we lack a certain form of experience. In the language of one of our famous Latin writers, "Without a knowledge of the past the world must remain in the infancy of knowledge."

The present contribution to the Historical Section has been suggested by the Chairman of this Division, otherwise the writer would have scarcely persuaded himself to undertake its writing. In doing so he wishes simply to offer his mite to the common fund of pharmaceutical narratives and portrayals of the vocation as seen through his eyes when an apprentice in the 6o's. A fragment only of early personal observations and experiences may possibly add to the value of our historical depository and be interesting to those who may follow after us in line of beginners in pharmacy.

In Bridgeton, New Jersey, in the sixties, there was located what was considered one of the largest drug establishments of that time in that section. It was conducted and owned by the firm Robeson \& Whitaker. The writer, directed by fortune or fate, was led into the employ of this firm as an apprentice. The building, in which this large business was conducted, consisted of three stories. The top story was occupied by a candy manufactory. Here was employed an expert in the confectionery art. His assistant was a drug apprentice. To this position the writer was first assigned. One may well ask what candy-making has to do with the vocation of pharmacy, apparently a very extraneous vocation. But one who had even an apprentice's experience in the art of manipulating sugar into various forms of confectionery and in that of preparing the various harmless coloring matters with which to decorate these sweet meats, can testify to its value to an apprentice in the druggist's vocation. The word itself, confectionery, is derived from the Latin word "Conficere" (to make up together), which is, after all, the basic principle of pharmacy, which is to compound. An apprentice who would make good in the third floor of this drug house was promoted to the second floor of the establishment, which might be designated as the bottling and packing department. From thence to the first floor or salesroom. Here on the second floor were bottled Godfrey's Cordial, Bateman's Drops, Turlington's Balsam, Laudanum, Paregoric, Number 6 and other domestic remedies in great quantities which were sold to the country trade. Large and commodious vehicles, known as the "Medicine Wagons" were packed every Monday morning for a week's trip, between four and five o'clock, and started on their way to visit the various towns between Bridgeton and Atlantic City, and Bridgeton and Cape May. 'These were sent out each week having a route for the distribution of these domestic remedies, con-

* Read before Section on Historical Pharmacy, A. Ph. A, Atlantic City meeting, Igr6. 
fectionery, cakes, ginger snaps, tobacco, cigars, etc., to the country merchants who kept these agents in stock.

In passing, permit your historian to call attention to the famous Number 6, one of the popular remedies of that time, of which Tinctura Capsici Compositus is a lineal descendant. I recall that we had in that city at that time a famous Thomsonian who had considerable practice and his Number 6 remedy was quite popular. It may not be out of place to here record (what interested me much in those days) something of a description of this now defunct practice and something of the author of it, whose history has almost faded away from current literature. By the Thomsonian system the human body is assumed to consist of four so-called elements, fire, air, earth and water. Metals and minerals, being ponderous and tending earthward, were supposed to drag down to the earth those who used them in medicines, while vegetables, springing from the ground, are fitting to make those who employ them as remedies to move upward to life and health. Thomson, who was born in 1769 , was an uneducated man. He tells us that he went to school for only one month when he was ten years of age, but his writings were remarkable for their terseness, clearness and vigor of language. In I 805 , when he was 36 years of age, he determined "to make a business of doctoring," so says his historian, and depend solely upon that natural gift of healing which he and his neighbors thought nature and nature's God had given him. We have many such so-called medical theorists to-day, unfortunately. Among other books, he published a work, The New Guide to Health, or Botanic Family Physician, Containing a Complete System of Practice on a Plan Entirely New, giving direction for preparing and administering his cures. One of his doctrines was to keep the stomach warm and empty and the skin sweating. He decreed that all serious diseases were caused by canker in the stomach, one degree causing measles, another scarlet fever, another small-pox, etc. If the inside of the stomach was "left cold," it must be warmed up by Number 2, or cayenne pepper, for cold was the cause of all disease and death while heat was the origin of all life and health. For the same reasons the skin should be kept hot and sweating by steam baths. If any one became nervous or was thrown into cramp convulsion-fits, Number 3 , or nerve root, or skunk cabbage, was used. He even put his practice into rhymes, thus:

The Emetic, No. I's designed

A general medicine for mankind

Of every country, clime or place,

Wide as the circle of our race.

In every case and state and stage,

Whatever malady may rage,

In male or female, young or old,

Half its value can't be told.

Let No. 2 be used bold,

To clear the stomach of the cold.

Next take the coffee No. 3 ,

And keep as warm as you can be. 
When sweat enough, as we suppose,

In spirit wash and change your clothes.

Then get in bed, both clean and white

And sleep in comfort all the night.

Now take your bitters, etc.

He gave singular names to his medicines, so says his historian. Lobelia he called ram-cats; cayenne pepper, bulldogs; marsh rosemary and bay-berry bark, coffee.

It is to be noted that Samuel IIahnemann's system of medicine was regarded as the exact opposite of 'Thomson's as regards doses but not as regards principles, for he gave cayenne pepper, hot drops, lobelia and other violent irritants in fevers and inflammations.

Thomson lived in times of great epidemics of scarlet and typhoid fevers, diphtheria and cerebro-spinal meningitis. His book is crowded with cases of severe disease imperfectly reported but still of some historical if not of scientific value.

In 1812 he went to Washington to take out a patent for the use of lobelia in fevers, colics, dysenteries, etc. and for his steam-sweating. Dr. Thornton and the celebrated Dr. Samuel L. Mitchell were very patient with him, as were Drs. Rush and Barton in Philadelphia. He came back with some sort of a patent, and refused to treat any person who did not join his Friendly Medical Society, take out a family right to practice his system, and pay $\$ 20$ therefor.

The Thomsonian doctor made great impression on the writer, it is needless to say.

Historically, we are told, the pharmacist has a good right to be called a chemist. Looking back upon that period of a half century ago, as the writer sees it now, the pharmacists of that day in smaller towns were far behind in the qualifications requisite to claim such a title. The compounding required called for little or no knowledge of chemistry.

The writer recalls his duties in the bottling and compounding department in cutting up opium for maceration and extracting the numerous lead bullets which were returned to the wholesaler and thence to the source of supply for a recovery of claims. At odd moments he was pounding vigorously upon an iron mortar with the heavy pestle to bring to proper commintution some fibrous drug, or was grinding upon a $\mathrm{CO}_{2}$ generator, mixing whicing with $\mathrm{H}_{2} \mathrm{SO}_{4}$, generating and forcing the gas into copper containers of water to make the soda water. He used to wonder how soda water could be made from common whiting and sulphuric acid. The proof was the fact that soda water was so made. It was a question whether even the proprietor or chief clerk could explain the simple reaction which takes place when the acid and alkaline ingredient of Seiditz Powder were mixed with the proper vehicle. It was the consciousness of this prevailing ignorance of what was considered the essentials of the drug business that sent this apprentice to college much against the advice and prejudice of his employers and fellow clerks. Philadelphia, a wonderful city to a country boy, was regarded the Athens of the world and the Philadelphia College, in his imagination, was its 
highest temple of pharmaceutical learning. It should be recognized, of course, that a mere apprentice could not make very trustworthy observations, but as the writer looks at it from his present standpoint, and from the standpoint of pharmacy, as he viewed it in those days in a small city of about five or six thousand, pharmacy has made quite appreciable advances. The average pharmacist is on a higher plane and the apprentice is much better provided for. The pharmacists of Bridgeton, New Jersey, I doubt not, all have and use the United States Pharmacopoeia and regard it, as they did not in those days, as an authoritative guide in the preparation of remedial agents. The Board of Pharmacy of New Jersey has honored for years my early associate, Henry A. Jorden, as one of its worthy members. The extraneous merchandise, such as toys, especially at Christmas time, have been displaced by more pharmaceutical-like commodities. As I look over the past fifty years I have vividly before me the impression that the ideal pharmacist cherished as an ideal the notion of operating a drug store in which only physicians' prescriptions were compounded, but every one knows how commercialism has crept into both pharmacy and medicine to prevent this-both are to blame. Another observation your historian has made: the pharmacist has seen fit, in battling with adverse conditions, to substitute for the harder, the more seanty, and more professional side of his vocation, such as microscopical analysis, food and drug analysis, sanitary analysis and even industrial analysis-has substituted these, following a line of least resistance, the various commercial ventures in many drugless sundries, such as every possible kind of extraneous merchandise. Each age has its own problems which men who live in must solve. The past in pharmacy has been more truly representative than the immediate present. Would it not pay us to consider this phase of the question seriously and march into the future in a resolute way determined to make pharmacy more professional and scientific?

\section{A NEGLECTED LESSON.}

At the close of the Civil War the need for a corps of pharmaceutical chemists in the medical supply department was set forth by no less an authority than Professor John M. Maisch. At the close of the Spanish War the Dodge Commission pointed out the blunders in the medical supply service as then organized. At the close of the present war there will no doubt be a commission to point out again the fact that our medical supply department might be better organized than it is now. But it will then be too late to profit by the experience of two wars and by that of England itself. The British Army is founded on caste. 'The British officers were drawn, at least at first, from the aristocracy and landed gentry. To suggest to one of these aristocrats that a "chemist," a mere tradesman, should be given a commission rank came near being sacrilege. We follow the British precedent. Caste-ridden Germany does not take this fallacious view, but does give commissions to pharmacists. Even the English colonies of Australia and Canada take a broader view of the situation and have accorded commissioned rank to pharmacists. If the pharmacists of the United States could bring their united pressure to bear upon our Government, we, too, would have commissions for our pharmacists.-Editorial Comment, American Druggist, April, I9I7. 